\title{
Die WAT en etimologie: Word die kringloop voltooi?
}

\author{
Willem Botha, Buro van die Woordeboek van die Afrikaanse Taal, \\ Stellenbosch, Suid-Afrika
}

\begin{abstract}
The WAT and etymology: Will the cycle be completed? Afrikaans historical lexicography is a neglected discipline and to a large extent metalexicographers hold the overall-descriptive Afrikaans dictionary, Die Woordeboek oan die Afrikaanse Taal, responsible for this state of affairs. The WAT, however, describes itself as a synchronic dictionary aimed at describing the present usage of Afrikaans. Limited etymological information is included. Ironically it was the ideal of the first editor of the WAT that it should contain concise etymological information on the whole of the Afrikaans lexicon. This task however, proved to be well beyond his reach and future editors did not believe a historical description of Afrikaans to be the aim of the synchronic WAT. Practical proposals are made for the satisfactory presentation of etymological information on the Afrikaans lexicon.
\end{abstract}

Keywords: ETMMOLOGY, ETYMOLOGICAL DICTIONARY, HISTORICAL LEXICOGRAPHY, OUTSIDE-AUTHORS, SATELLITE PROJECTS, SECONDARY ETYMOLOGICAL SOURCES, SYNCHRONIC DICTIONARY

Opsomming: Die Afrikaanse historiese leksikografie is ' $n$ verwaârloosde dissipline en in die metaleksikografie word die vinger na die Woordeboek zan die Afrikanse Taal se wegskram van etimologiese inligting gewys as een van die hoofoorsake van hierdie toestand. Die WAT beskryf homself egter as 'n omvattende sinchroniese woordeboek wat hoofsaaklik gerig is op die hedendaagse taalgebruik. Tog was dit die ideaal van die eerste hoofredakteur om bondige etimologiese inligting by elke lemma te verskaf - ' $n$ taak wat geblyk het ver buite sy en toekomstige redaksies se bereik te wees. Praktiese voorstelle word gemaak vir die bevredigende aanbieding van etimologiese inligting oor die Afrikaanse leksikon.

Sleutelwoorde: BUTTE-OUTEURS, ETIMOLOGIE, ETIMOLOGIESE WOORDEBOEK, HISTORIESE LEKSIKOGRAFIE, SATELLIETPROJEKTE, SEKONDERE ETIMOLOGIESE BRONNE, SINCHRONIESE WOORDEBOEK

\section{Inleidend}

Dit ly geen twyfel nie dat die historiese leksikografie die mees verwaarloosde dissipline van die Afrikaanse taalkunde is en inderdaad nog in sy kinderskoene staan (Gouws en Ponelis 1992). In die metaleksikografie word die vinger na die Woordeboek van die Afrikaanse Taal se afskeep van etimologiese inligting 
gewys as een van die grootste bydraende faktore tot hierdie toestand. Die WAT beskryf homself egter as 'n omvattende sinchroniese woordeboek "wat hoofsaaklik gerig is op die hedendaagse taalgebruik" (Van Schalkwyk 1994: i). Betekenisonderskeidings word nie in historiese volgorde gegee nie, maar word van die hoogste na die laagste gebruiksfrekwensie, tydens bewerking, gerangskik.

Die situasie rondom etimologiese inligting in die WAT was egter nog nooit staties nie. Dit het geëvolueer van ' $n$ gestelde ideaal van bondige etimologieë by elke lemma na geen etimologieë nie; dáárna na die selektiewe aangawe van etimologieë, en laastens na die insluiting van beperkte etimologiese inligting op 'n selektiewe basis.

In hierdie artikel word ondersoek ingestel na oplossings vir die bevredigende aanbieding van etimologiese inligting oor die Afrikaanse leksikon.

\section{Historiese verloop van historiese inligting in die WAT}

\section{1 'n Ideaal word nagestreef: Die WAT as eerste bron van etimologiese inligting oor die Afrikaanse leksikon - 1926-1945}

Prof. J.J. Smith, verbonde aan die destydse Departement Hollands-Afrikaans aan die Universiteit van Stellenbosch, is in 1926 as eerste hoofredakteur van die WAT aangestel. Die vraagstuk oor die ontstaan van Afrikaans was in dié jare op die voorgrond en prof. Smith het sy eerste en laaste openbare lesings aan dié onderwerp gewy. Smith se standpunt was dat Afrikaans spontaan uit 17de-euse Nederlands ontwikkel het en dit is nie onwaarskynlik nie dat hy sy opvatting oortuigend wou bewys deur die aanbieding van gegewens van die taal self in die WAT (Gericke 1991: 75-76). Aangesien byna geen etimologiese navorsing in dié tyd bestaan het nie, het Smith hom in die voorbereidingswerk vir die WAT, al hoe meer in etimologiese navorsing verdiep.

'n Paar "proefdefinisies" is in 1936 in die Stellenbossche Oudstudent gepubliseer in die hoop dat belangstellendes welwillende kritiek aan die hoofredakteur sal stuur. Dit is insiggewend dat etimologiese gegewens kortliks aan die einde van elke artikel tussen vierkanthakies gegee is (Gericke 1991: 55). Dit was in ooreenstemming met Smith se viteensetting van die samestelling van die WAT in Die Suiderstem van 13 Febr. 1937. Daarin verduidelik hy dat die herkoms van elke grondwoord, onduidelike samestelling of afleiding aan die einde van die artikel gegee sal word. Dit sou baie bondig wees: "net genoeg om aan die nie-vakkundige leser te sê of die woord uit Nederlands geërf of aan 'n ander taal ontleen is" (Smith 1962: 101).

Die aangawe van etimologie was bewys van Smith se ideaal om gestalte te gee aan ' $n$ wetenskaplike verklaring van die herkoms van die Afrikaanse leksikon. Die studie van allerlei plaaslike taalreste en vervorminge kon 'n verrassende lig werp op die vraagstuk van herkoms. Dit moes egter verbind word 
met die studie van ou bronnemateriaal en daar moes in Nederlands, Frans, Duits, Portugees, die ander inheemse tale en veral in die Nederlandse dialekte gesoek word na gegewens met betrekking tot moontlike vertrekpunte en ooreenkomste (Gericke 1991: 76).

\subsection{Die realisme seëvier: Geen etimologie in 'n oorwegend sinchroniese woordeboek nie - Deel I tot IV}

Die selfopgelegde taak van etimologiese navorsing het egter só baie van Smith se tyd in beslag geneem dat dit as een van die oorsake geïdentifiseer is waarom daar in 19 jaar niks gepubliseer is nie. Ironies genoeg het baie min konkrete bewys van dié navorsing behoue gebly. 'n Deel daarvan lê verskuil tussen die vier miljoen optekeninge in kaartvorm in die databank van die WAT. Die grootste deel daarvan was waarskynlik deel van sy persoonlike wete en is nêrens opgeteken nie. 'n Enkele publikasie waarin van sy navorsing vervat is, het in 1962 verskyn, nl. Op ons taalakker. Hierin is die artikels byeengebring wat hy vir die gelyknamige taalrubriek in Die Suiderstem geskryf het.

Die tydrowendheid van prof. Smith se etimologiese navorsing het daartoe aanleiding gegee dat daar uiteindelik besluit is op ' $n$ oorwegend sinchroniese WAT. Daar is verder geoordeel dat etimologieë, hoe interessant ook al, nie noodsaaklik is vir betekenisbeskrywing in 'n sinchroniese woordeboek van Afrikaans nie (Hauptfleisch 1989: 12). Met die aanstelling in 1946 van dr. P.C. Schoonees, hoofredakteur van dele I-IV, het die Raad van Beheer gekonstateer dat afgesien word van die opname van etimologiese inligting.

Daar is egter wel in 'n mate etimologiese inligting verstrek in dele I tot V aangesien die herkomstaal by leenwoorde en leenwoordgroepe aangegee is, bv. aperto libro (L.), bric-à-brac (Fr.), Cockney (Eng.), Führer (D.), juvenilia (L.), kalamaika (Hongaars), kalambak (<Mal.).

\subsection{Etimologie op 'n selektiewe skaal: Deel VI tot VIII}

Na die verskyning van Boshoff en Nienaber se Afrikaanse Etimologië in 1967 het die redaksie besluit om op 'n selektiewe skaal "etimologiese aanduidings" te gee, in die besonder by Afrikaanse woorde wat inheems ontstaan het, omdat sulke etimologieë nie geredelik in ander bronne beskikbaar is nie. Die besluit het vervolgens in WAT VI tot VIII neerslag gevind.

Die aangawe van etimologieë het daarop neergekom dat etimologie in beginsel wel gegee is by inheemse Afrikaanse woorde sowel as by leenwoorde en leenvertalings uit nie-Suid-Afrikaanse tale.

Dit is egter nie gegee by Afrikaanse woorde van direkte Nederlandse herkoms nie. Die ratio hieragter was dat die herkoms van hierdie gedeelte van die Afrikaanse woordeskat in Nederlandse etimologiese en verklarende woorde- 
boeke soos veral die WNT nageslaan kon word. 'n Uitsondering is gemaak in die geval van Ndl. leenwoorde uit ander tale.

Die etimologie is een of twee stappe terug gevoer tot deursigtigheid bereik is, bv. krieket ( $<E$. cricket), heemkunde (via N. $<D$. Heimatkunde, "kennis v.d. aarde, geografie en folklore v.d. eie land"). Die woord in die herkomstaal is nie in sy dele verdeel en die dele afsonderlik verklaar nie. By gevalle van onsekere etimologie is die etimologie gekwalifiseer deur moontl./waarsk. daarvoor te plaas. Die etimologiese gegewens is volgens 'n vaste stelsel by verskillende tipes woorde gegee, bv. leenwoorde (genre $(F .$, "soort")) en basterleenwoorde (hokkie (<E. hockey)).

In Deel VII het onder andere die volgende voorbeelde volgens die beleid van selektiewe etimologiese inligting verskyn:

kombers', komberse; kombersie. ( $<N$. kombaer(t)s, kombe(e)rs, kombaars, "skeeps- en soms soldatekombers", waarsk. 'n verbastering van Port. coberta, "bedekking vir ' $n$ bed")

Soos in baie ander gevalle is bg. ' $n$ verbetering en verheldering van Boshoff en Nienaber se inskrywing.

kondens'melk. (kondens: $<E$. condensed).

kon'trabande. Ook soms kontraband. (<It. contrabando, F. contrabande).

ko'nka, konkas; konkatjie. Ook soms ghonka, katonka, kongha, tjonka, tonka, (<X. inkonkxa, "blik", (i)t(h)unga (ilit(h)unga), "(melkemmer)";

$<Z$ i(li)t(h)unga, "(melk)emmer").

kombuis', kombuise; kombuisie. Ook soms i.d. spreektaal kambuis. (via N. <Mnl. cabuse, "voorraadkamer; kookruimte op 'n skip").

kong'si, kongsi's. (via $N$. <Sjinees).

komboloi, komboloia (G.) of kombolois.

Soms word die etimologiese gegewens nie in die gleuf daarvoor aangegee nie, maar op ' $n$ indirekte wyse in die sitate. By ' $n$ woord soos koerant wat via Ndl. uit die Frans ontleen is en nie meer as 'n leenwoord aangevoel word nie, word uitgebreide etimologiese inligting uit Johan Combrink se Waar kom daardie woord vandaan? in 'n sitaat aangegee. 'n Soortgelyke prosedure word gevolg by o.a. koejawel, kanferfoelie en kraakporselein.

\section{Etimologie in 'n sinchroniese woordeboek: 'n Metaleksikografiese perspektief}

In die metaleksikografie is daar periodiek uitsprake gemank oor die opname van etimologiese inligting in 'n sinchroniese woordeboek en, meer spesifiek, in die WAT. 
Scholtz (1972: 107) spreek hom sterk uit teen die opname van etimologieë in die WAT. Hy sê onder meer: "Die WAT is nie veronderstel om etimologieë te gee nie ... Dit lyk my wenslik dat die WAT hom tot sy eintlike taak bepaal, om ons so 'n volledig moontlike inventaris en beskrywing van die hedendaagse Afrikaanse woordeskat te gee. Die tyd het nog nie gekom dat ons 'n woordeboek van Afrikaans op historiese grondslag kan aanpak nie. Daar sal nog enorm baie materiaal versamel en voorstudies geskrywe moet word."

Alhoewel hierdie uitspraak reeds 24 jaar gelede gemaak is, dui die stand van navorsing daarop dat die situasie nie wesenlik verander het nie.

L.C. Eksteen (1976) deel nie Scholtz se siening nie en is van mening dat daar genoeg materiaal beskikbaar is sodat dit moontlik en wenslik is om 'n Afrikaanse woordeboek op historiese grondslag te begin. Hy meld ook dat daar in die hedendaagse leksikografie 'n vermenging van diachroniese en sinchroniese praktyke voorkom. Sinchroniese woordeboeke gee dikwels ook historiese inligting, soos kort etimologiese verwysings.

Volgens Gouws (1989: 64) maak Scholtz in sy siening oor die aangawe van etimologiese inligting nie voorsiening vir die inligtingsoorvleueling wat in verskillende woordeboektipes voorkom nie. Talle sinchroniese woordeboeke sluit ook etimologiese inligting as ' $n$ mikrostruktuurelement in. Selfs historiese inligting soos die dagtekening van die eerste optekening van 'n woord se gebruik, word soms gegee. Dit is volgens hom ook die geval met die WAT wat baie inligting bevat wat binne die historiese woordeboek se terrein val.

Gouws en Ponelis (1992) spreek die mening uit dat die eise van omvattende historiese leksikografie ver buite die bereik van selfs twee sulke uitsonderlik skerp en ywerige intellekte soos dié van Boshoff en Nienaber val en dat bittermin etimologiese navorsing reeds gedoen is: "Though valuable work has been done, Afrikaans historical lexicography is still in its infancy. The discipline faces a challenging and daunting task well beyond the most passionate dedication of individuals."

Hulle voer verder aan dat die term "omvattende sinchroniese woordeboek" 'n contradictio in terminis is, aangesien 'n omvattende woordeboek se bestek nie beperk kan word tot slegs 'n sinchroniese beskrywing van die taal nie. Die taak van die WAT is volgens hulle om meer as sinchroniese inligting te gee.

In resensies van die WAT-dele, wat vir lank die enigste vorm was waarin die metaleksikografie in Afrikaans beoefen is (Gouws (moet nog verskyn)), word dikwels kritiek gelewer op die hantering van etimologiese gegewens.

In haar resensie van die agste deel van die WAT sonder Edith $H$. Raidt (1993) die wegskram van etimologieë en die afwesigheid van historiese beginsels uit as tekortkominge in dié deel. Haar kritiek is teen die "hibridiese opset van die WAT as 'n verklarende woordeboek wat slegs nou en dan etimologies, en slegs nou en dan histories te werk gaan." Volgens haar weerspieël dié benadering die leemtes in die leksikografie van Afrikaans, nl. "ons besit geen historiese woordeboek van Afrikaans nie, en die etimologieë van woorde is maar 
net gedeeltelik beskryf." Sy gaan dan egter voort deur te sê: "Daar is beslis reeds baie navorsing gedoen en talle etimologieë is goed nagevors; bestaande studies soos die van Boshoff en Nienaber en Scholtz behoort deeglik benut te word."

Indien die WAT hierdie bronne "deeglik" sou benut, sou hy nog steeds 'n hibridiese karakter hê, omdat die WAT soveel meer leksikale items opneem as wat die genoemde bronne behandel. Die etimologiese navorsing in die betrokke bronne is dikwels van 'n bespiegelende aard, wat die opname daarvan in die WAT, waarvan die inhoud as gesaghebbend beskou word, problematies maak. Verdere navorsing word dikwels vereis wat baie tydrowend kan wees.

Op 25 November 1989 begin 'n polemiek in Die Burger oor etimologiese inligting in die WAT wat voortgevloei het uit 'n verdoemende artikel gemik op die WAT op 18 November deur die uitgewer Koos Human. Die bekendste onder die polemici was Wilhelm Grütter, rubriekskrywer van Die Burger wat aanvanklik die aantyging maak dat die WAT geen etimologieë verskaf nie terwyl dit van hom verwag kan word; daarna dat etimologieë op inkonsekwente wyse opgeneem word. Na reaksie van Botha (1989) en Hauptfleisch (1989) is dit veral Harteveld (1989 en 1990) wat oënskynlik daarin slaag om bevredigende antwoorde te verskaf aan die ontevrede gebruikers. Die kem van Harteveld se verweer was dat die bestaande etimologiese navorsing ontoereikend is, dat die WAT nie oor die personeel, tyd en geld beskik om etimologiese navorsing te onderneem nie, dat etimologiese inligting in 'n sinchroniese woordeboek soos die WAT, soos ander historiese inligting, as 'n bonus beskou moet word en dat die tydgenootlike beskrywing van woordbetekenisse in die WAT die belangrikste is.

\section{Etimologie op 'n selektiewe en beperkter skaal: Deel IX}

Na die voltooiing van Deel VIII, en die letter $K$, was die beplanning van die WAT primêr op verkorting en versnelling gerig. As deel van die versnelling van die werk aan die WAT is daar in 1989 besluit om die aangawe van etimologiese inligting vanaf Deel $\mathrm{D} X$ te verminder. Intensiewe navorsing oor die herkoms van woorde is as te tydrowend beskou omdat daar nie 'n enkele volledige etimologiese bron in Afrikaans bestaan nie en omdat die redakteurs in gebrekkige kennis van die historiese taalkunde het. Die ingewikkelde hanteringswyse van etimologiese inligting was 'n bydraende tydrowende faktor.

Die redaksie het besluit om minder etimologiese inligting te gee, alhoewel hulle bewus was van:

- die sterk aandrang van die gebruiker op meer en uitgebreide etimologieë,

- die feit dat Gouws (1989: 64) en Eksteen (1976: 67-75) aangetoon het dat sinchroniese woordeboeke dikwels etimologiese inligting insluit, 
* dat daar benewens die etimologieë in Boshoff en Nienaber se Afrikaanse Etimologieë en die WNT ook enkele ander etimologiebronne bestaan

- en dat dit sou lei tot 'n vergroting van die hibridiese karakter van die WAT.

Daar is onder andere aangevoer dat alhoewel daar enkele etimologiese bronne bestaan, etimologiese inligting selde onveranderd uit ' $n$ ander bron oorgeneem kan word (vgl. die behandeling van konka in die WAT en in Boshoff en Nienaber) en dat oënskynlik eenvoudige gevalle verskillend behandel word in verskillende bronne (vgl. die behandeling van camouflage).

Daar is tot die slotsom gekom dat die beplanning van die WAT primêr op verkorting en versnelling gerig is en dat etimologie op die toe heersende of op 'n uitgebreide skaal slegs verskaf kan word indien 'n bykomende redaksielid met ' $n$ taalhistoriese opleiding aangestel word.

In Deel LX van die WAT is etimologiese inligting in die volgende gevalle aangebied:

- Leenwoorde en leenwoordgroepe wat onveranderd in Afrikaans opgeneem is en waarvan die ortografie as vreemd aangevoel word, ongeag daarvan of dit via ' $n$ ander taal opgeneem is en of dit na betekenis van die herkomswoord verskil, bv. lady s.nw. (Eng.), lazaretto s.nw. (It.), kunsestablishment s.nw. (establishment (Eng.)).

- Voorbeelde van volksetimologie, bv. katjiepiering s.nw. (volksetim. <Mal. katjapiring, "glasbakkie"), hanepoot s.nw. (poot: wsk. volksetim. <Ndl. kloot, "teelbal"), lewensliksens s.nw. (liksens: volksetim. <essens).

- Simplekse, samestellings, uitdrukkings en ander woordgroepe wat van 'n eienaam afgelei is of waarin 'n eienaam voorkom, bv.: leotard s.nw. (na J. Leotard, Fr. sweefstokarties), limerick s.nw. (na Limerick, stad en graafskap in Ierland) liebigkondensator s.nw. (na J. von Liebig, D. chemikus), lesbiër s.nw. (na Lesbos, tans Mutilene, 'n eiland i.d. Egeiese see).

- Waar iets wat eg Afrikaans is, deur 'n vorm uit 'n ander taal verdring word, bv. lighuis s.nw (n.d. Eng. lighthouse), lanskorporaal s.nw. (lans: n.d. Eng. lance), die laaste strooi of die laaste strooi wat die kameel se rug breek (n.d. Eng. the last straw of the last straw which breaks the camel's back).

* Afrikaanse letterwoorde en verkortings, bv. vigs s.nw. (<verworwe immuniteitsgebreksindroom).

5. Kritiek op die hantering van etimologiese inligting in Deel IX van die WAT

Na voltooiing van Deel $\mathrm{DX}$ in 1994 in die rekordtyd van twee en 'n half jaar het die hoeveelheid beskikbare etimologiese inligting wat as gevolg van die nuwe 
stelsel verlore gaan, redaksielede opnuut laat nadink oor die aangawe van etimologiese inligting. Veranderings in die aanbod van etimologiese inligting is aanvanklik vir Deel $\mathrm{X}$, wat die letter $\mathrm{M}$ omvat, oorweeg, maar is laat vaar ten einde nie die werk aan die deel te vertraag nie.

Feinauer (1996) is in haar resensie van Deel DX van die WAT van mening dat die WAT dit moet oorweeg om etimologiese inligting uit te brei om ook "bepaalde" uitdrukkings in te sluit: "Uitdrukkings in Deel IX wat hulle leen tot etimologiese toeligting is bv.: die lakens uitdeel, onder die loep neem, op die lappe kom, op jou louere rus." Sy meld nie watter maatstawwe aangelê moet word om te ontkom aan die kritiek van inkonsekwente aangawe van etimologiese inligting nie as bv. van die navorsing van D.F. Malherbe (1925) en J. du P. Scholtz (1985) gebruik gemaak sou word.

\section{Moontlike opsies vir die bevredigende verskaffing van etimologiese inligting}

\subsection{Aanpassing van die huidige aanbod van etimologiese inligting in die WAT}

'n Hinderlike aspek van die hantering van etimologiese inligting in Deel IX is dat daar by leenwoorde waarvan die skrifbeeld minimaal van die herkomstaal verskil, geen etimologiese inligting verstrek word nie, bv. lasaret (It. lazaretto), lasso (Sp. lazo), lechaim (Hebr. lechayim), letieng (So. leting). So gaan 'n aansienlike hoeveelheid beskikbare etimologiese inligting verlore.

Steeds uitgaande van 'n primêre ingesteldheid op versnelling en verkorting kan daar deur ' $n$ geringe aanpassing in die stelsel voorsiening gemaak word vir bogenoemde gevalle. By leenitems waarvan die ortografie as vreemd aangevoel word en die Afrikaanse skrifbeeld verskil van dié van die leentaal, kan die verskil aangedui word, bv. lasaret ( $<I t$. lazaretto), moretla ( $<$ So. moretlwa), nabob (<Port. nababo). In die Toeligting kan gesê word dat die aanduiding (<herkomstaal) nie noodwendig beteken dat dit 'n direkte ontlening is nie. Dieselfde sou ook gesê kon word van die aanduiding van die herkomstaal in gevalle soos largo (It.) en restaurant (Fr.).

Indien daar ' $n$ verskil in betekenis in Afrikaans ingetree het, moet die betekenis in die herkomstaal aangedui word, bv. mpata (<Z. umphata, "iemand wat nie goed begryp nie"), nausea (<Gr. nausia, "seesiekte").

By samestellings waarvan die eerste of laaste komponent ' $n$ leenwoord is, kan dieselfde hantering gevolg word, bv. nabadingetjie (naba: Nama, "om te blink" of mntl. <Nama gabba, "beker, skottel"), narkohipnose (narko: <Gr. narke, "verlamming"), nabank (na: hou mntl. verband met Nama !na, benaming vir 'n groot skilpadsoort of met Nama !noa, "grys").

Dit is egter te betwyfel of dié geringe aanpassing 'n bevredigende oplossing is vir die leemtes rondom etimologiese inligting in Deel IX van die WAT. 


\subsection{Etimologiese inligting by elke lemma in die WAT deur gebruikma- king van sekondêre bronne}

'n Radikale oplossing sou wees om etimologiese inligting by elke lemma te oorweeg. Dit is haalbaar indien slegs gebruik gemaak word van alle beskikbare sekondêre bronne en geen oorspronklike etimologiese navorsing gedoen word nie. Die strewe moet nie wees na 'n historiese oorsig van die morfologiese of fonologiese ontwikkeling van leksikale items nie, maar die klem moet val op betekenis. Dit gaan dus nie in die eerste plek oor die oorspronklike vorm en die veranderings wat in die loop van die geskiedenis daarin plaasgevind het nie, maar oor die ontwikkeling in die betekenis en die verheldering wat dit bring ten opsigte van die huidige betekenis van die item.

Indien daar by leengoed nie enige bewys is van interessante betekenisontwikkeling nie, word slegs die taal van herkoms aangedui. Dit beteken nie noodwendig dat dit 'n direkte ontlening is nie, bv. nasi goreng (Mal.), lasaret (<It. lazaretto). Daar word nie daarop ingegaan of die woord via 'n ander taal ontleen is nie, omdat dit soms tydrowend of selfs onmoontlik is om presies vas te stel langs watter weg ' $n$ item 'n bep. leksikon bereik het. So is Nederlandse etimoloë onseker of narkotiseur aan Frans of Duits ontleen is en is dit raadsaam om slegs die verband met Latyn en Grieks aan te dui: narkotiseur ( $<N d l$. narcotiseur < Lat. narcoticus <Gr. narkotikos <narkoun "verlam" <narke "verlamming").

By erfgoed moet daar sprake wees van interessante betekenisontwikkeling in die historiese verloop van die Ndl. woord, of die Afr. woord moes in vergelyking met sy Ndl. ekwivalent interessante betekenisontwikkeling ondergaan het of deur iets eiesoortig gekenmerk word, anders word slegs aangedui dat die woord $\mathrm{Ndl}$. van herkoms is, bv. naaf $(\mathrm{Ndl}$.). In Van Dale se Etimologisch Woordenboek (1991) word bv. die volgende inligting by naaf verskaf:

naaf (middenstuk waardoor de as gaat) middelnl. nave, na(e)f, oudsaksisch naba, oudhd. naba, oudeng. nafu, oudnoors nof; buiten het germ. oudpruisisch nabis, oudindisch nabhya - [naaf].

Hier is dus geen sprake van inligting oor betekenisontwikkeling nie, maar slegs van 'n morfologiese oorsig binne en buite die Germaanse taalfamilie.

Versigtigheid moet aan die dag gelê word om nie sonder meer te sê dat een woord "uit 'n ander kom nie" en in navolging van Boshoff en Nienaber en ander bronne kan gesê word dat 'n woord "verband hou" of "korrespondeer" met, of volgens die Ndl. bronne "beantwoord aan", 'n ander. Daar hoef selde na die, vir ons, onbekende en veraf lede van die taalfamilie soos Noors, Oudfries, Oudhoogduits, Goties en Sanskrit verwys te word, maar soms kan na die voorkoms van 'n woord in die ander Germaanse tale verwys word, of aangedui word dat 'n woord verband hou met Latyn of Grieks of Engels omdat daar ' $n$ mate van bekendheid daarmee by gebruikers bestaan. Dit kan gesin- 
jaleer word deur die leestekengebruik wat dit voorafgaan, bv. 'n kommapunt:

naak b.nw. Ook nakend en, verouderend, naakt. ( $<N d l$. naakt $<M n l$. naket, naect, nakent; Nhd. nackt, Eng. naked; hou verband met Eng. nude en Lat. nudus "kaal")

By wisselvorme kan slegs etimologiese inligting gegee word by die vorm waar die definisie verskaf word:

nartjie s.nw., nartjies. Selde ook naartjie. (wsk. <Arab. naranj of mntl. $<$ Tam. nartei)

Lemmas word nie in komponente opgebreek ter verduideliking van hul vorming nie, maar waar slegs een komponent etimologiese inligting vereis, word slegs inligting oor daardie komponent verstrek, bv.

naberou: naberou is galberou idiomatiese uitdrukking (galberou: <Ndl. galg(e)berouw "berou uit doodsangs aan die voet van die galg" of "vals, onegte berou uit vrees vir straf en te laat getoon". Uitdr. onbekend in Ndl.)

nagmerrie s.nw. (merrie: Ndl. <Mnl. merrië volksetim. <mare "nagspook, kwelgees"; korrespondeer met Eng. (night)mare)

naboots ww., het nageboots. ( $<\mathrm{Ndl}$. nabootsen; bootsen: <O.fra. bocer "beeldhouwerk in reliêf maak" <boce "bult, verhewenheid")

Die skrywer het volgens bogenoemde riglyne etimologieë saamgestel vir alle items in die Buro se databank vanaf na tot Nazi. Daar is weer eens ondervind dat etimologiese inligting selde onveranderd uit ' $n$ ander bron oorgeneem kan word, veral omdat bronne van mekaar verskil. Dit is dan dikwels nodig om verdere navorsing te doen. Bronne wat met vrug gebruik is, is verklarende woordeboeke, nl. Oxford English Dictionary, Woordenboek der Nederlandsche Taal, Webster's (verskillende uitgawes), American Heritage Dictionary (verskillende uitgawes), A Latin Dictionary van Lewis en Short, Nouveau Petit Larousse; tweetalige woordeboeke, veral Engels / Nederlands, Nederlands / Engels; etimologiese woordeboeke, nl. De Vries (1971), De Vries / De Tollenaere (1991), Van Dale Etimologisch Woordenboek (1991), Boshoff en Nienaber (1967), Onions se The Oxford Dictionary of English Etymology (1969), Dictionary of South African English on Historical Principles (1991) en ander bronne, veral Scholtz $(1965,1972,1985)$ en Smith (1962). Konsultasie met kenners van vreemde tale het ook gereeld plaasgevind waar onsekerheid bestaan het.

Daar is heelwat leenwoorde uit Nama wat met $n a$ - begin en wat eiesoortige probleme vir die leksikograaf meebring., Baie van die woorde word met een van vier tipes suigklanke uitgespreek en benewens die na-spelling kom ' $n$ $g^{h}$-, $k a-, ~ h a-$ en tha-spelling dikwels ook voor: Waardevolle mededelings deur prof. J.A. Engelbrecht van Pretoria ten opsigte van uitspraak en herkoms is in 
die databank opgeneem. Die dentale (/), alveolêre $(=)$, palato-alveolêre (!) en laterale $(/ /)$ suigklanke word in die skrifbeeld in die etimologieveld aangedui omdat daar geen fonetiese tekens daarvoor bestaan nie:

na [na:] (met aanvangsuigklank) b.nw. (<Nama !na) Lekker of baie lekker.

Versnelling en die bereiking van doelwitte word 'n steeds dringender aspek vir die voortbestaan van die WAT. Alhoewel die redaksie besef dat die toepassing van bogenoemde beginsels waarskynlik die gebruiker se verwagtings sal bevredig, maak die vereistes van versnelling en die bereiking van doelwitte dit moeilik uitvoerbaar.

\subsection{Vennootskap in 'n Etimologiewoordeboek}

Die Buro het in 1992 begin om met die medewerking van buite-outeurs satellietpublikasies uit te gee. Woordkeusegids: 'n Kerntesourus van Afrikaans het in 1992 verskyn en Afrikaanse Idiome en ander Vaste Uitdrukkings in 1994.

Dit wil voorkom asof die enigste wyse waarop die Buro 'n bydrae kan lewer om die opvallende leemte in die Afrikaanse leksikografie te vul, die medewerking aan 'n etimologiewoordeboek is. In so 'n geval sal die woordeboek deur buite-outeurs saamgestel word, terwyl die Buro betrokke sal wees by die beplanning, administratiewe begeleiding en setwerk.

Sodanige woordeboek sou binne drie tot vyf jaar voltooi kan word indien 'n woordeboek van ongeveer 20000 inskrywings aangepak word. Dit sou ongeveer vier maal die omvang van Boshoff en Nienaber se Afrikaanse Etimologieë wees. Die groot voordeel van so 'n projek bo deurlopende etimologie in die WAT is dat gebruikers binne vyf jaar oor etimologiese inligting van $\mathrm{A}$ tot $\mathrm{Z}$ in Afrikaans sal beskik in plaas daarvan om te wag totdat die WAT tot by $\mathrm{Z}$ voltooi is. Die inligting vervat in die etimologiese woordeboek sou ook in toekomstige WAT-dele gebruik kon word.

\section{Ten slotte}

Die huidige redaksie van die WAT is nie onwillig om deurlopend etimologieë aan te bied nie. Die moontlikheid is inderdaad ondersoek deur middel van 'n proefloop toe etimologieë, met gebruikmaking van sekondêre bronne, saamgestel is vir die deel van die Afrikaanse leksikon wat strek vanaf na tot Nazi.

Versnelling en die bereiking van doelwitte het egter so 'n belangrike deel van die WAT se beplanning geword dat dit eenvoudig nie haalbaar is nie. Deur 'n etimologiewoordeboek as 'n satellietprojek tot stand te bring wil die Buro van die WAT egter ' $n$ bydrae lewer tot die vul van 'n leemte in die Afrikaanse leksikografie en ook iets tereg laat kom van die ideaal van sy eerste hoofredakteur. 


\section{Verwysings}

Botha, W.F. 1989. Brief. Die Burger, 6 Desember 1989: 12.

Combrink, Johan. s.j. Waar kom daardie waord vandaan? S.p.: Suid-Afrikaanse Uitsaaikorporasie.

De Klerk, W.J. en F.A. Ponelis. 1976. Gedenkbundel H.J.J.M. van der Merwe. Pretoria: Van Schaik.

Eksteen, L.C. 1976. 'n Woordeboek van Afrikaans op historiese grondslag. De Klerk, W.J. en F.A. Ponelis (Reds.). 1976: 67-75.

Feinauer, I. 1996. Die negende deel van die Woordeboek van die Afrikaanse Taal. Lexikos 6: 233 271.

Gouws, R.H. 1989. Leksikografie. Kaapstad: Academica.

Gouws, R.H. en F.A. Ponelis. 1992. The development of Afrikaans and the Lexicographical Tradition. Zgusta, L. (Red.). 1992: 77-104.

Gouws, R.H. (moet nog verskyn) Linguistische Theorie, lexikographische Praxis und das Woordeboek van die Afrikaanse Taal. Festschrift H.E. Wiegand.

Grütter, W. 1989. Briewe. Die Burger, 25 November 1989: 14; 13 Desember 1989: 12; 29 Desember 1989: 10.

Harteveld, P. 1989. Brief. Die Burger, 22 Desember 1989: 8.

Harteveld, P. 1990. Brief. Die Burger, 16 Januarie 1990: 10.

Hauptfleisch, D.C. 1989. Brief. Die Burger, 22 Desember 1989: 8.

Raidt, E.H. 1993. Die agste deel van die Woordeboek van die Afrikaanse Taal. Lexikos 3: 215-226.

Malherbe, D.F. s.j. (1925). Afrikaanse spreekwoorde en verwante vorme. Bloemfontein: Nasionale Pers.

Scholtz, J. du P. 1972. Afrikeans-Hollands in die agtiende eeu. Kaapstad: Nasou.

Scholtz, J. du P. 1985. Afrikaanse woorde en uitdrukkings * eiegoed of erfgoed?. Tydskrif vir Geesteswetenskappe 25(4): 235-290.

Smith, J.J. 1962. Op ons taalakker. Pretoria: J.L. van Schaik

Van Schalkwyk, D.J. (Red.). 1994. Woordeboek van die Afrikeanse Taal. Deel DX. Stellenbosch: Buro van die WAT.

Zgusta, L. (Red.). 1992. History, Languages and Lexicographers. Tübingen: Max Niemeyer. 